\title{
THE MOUND BUILDERS
}

\author{
BRYCE
}

8

125

79

885

MAI 


\section{бHE}

\section{Mound Builders.}

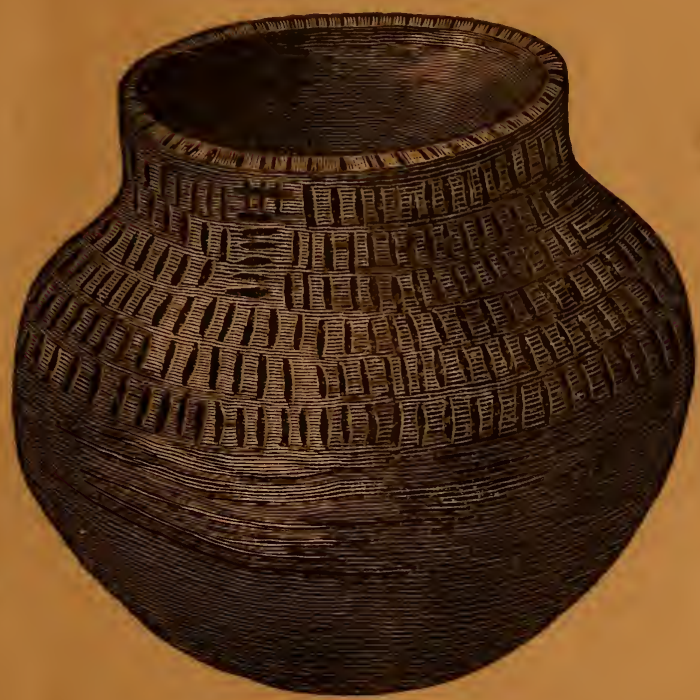

(Cup found in Mound at Rainy River, Aug. 22nd, 1SS4.)

PI

GEORGE BRYGE, M..F., LLL.D.,

Professor in Manitoba College and President of the Historical Society, Wimnipeg.

\section{PRICE, 25 CENTS.}

(Season 1884-85, Transaction 18.) (HISTORICAL SOCIETY.) 



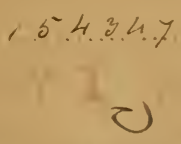

\section{бHE @OUND BUILDERS.}

A Lost Race Described oy Dr. Bryce, President of the Fistorical Society.

SEASON 1884-85.

Ours are the only mounds making up a distinct mound-region on Canadian soil. This comes to us as a part of the large inheritance which we who have migrated to Manitoba receive. No longer cribbed, cabined, and confined, we have in this our "greater Canada" a far wider range of study than in the fringe along the Canadian lakes. Think of a thousand miles of prairie! The enthusiastic Scotsman was wont to despise our level Ontario, because it had no Grampians, but the mountains of Scotland all piled together would reach but to the foot hills of our Rockies. The Ontario geologist can only study the rocks in garden plots, while the Nor'wester revels in the age of reptiles in his hundreds of miles of Cretaceous rocks, with the largest coal and iron area on the continent. As with our topography so with history. The career of the Hudson's Bay Company, which is in fact the histury of Rupert's Land, began 120 years before the history of Ontario, and there were forts of the two rival Fur Companies on the Saskatchewan and throughout the country, before the first U. E. Loyalist felled a forest tree in Upper Canada. We are especially fortunate in being the possessors also of a field for archaeological study in the purtion of the area occupied by the mound builders - the lost race, whose fate has a strange fascination for all who enquire into the condition of Ancient America.

The Indian guide points out these mounds to the student of history with a feeling of awe; he says he knows nothing of them; his fathers have told him that the builders of the mounds were of a different race from them-that the mounds are memorials of a vanished people-the "Ke-te-anish-i-na-be," or "very ancient men." The oldest Hudson's Bay officer, and the most intelligent of the native people, born in the country, can only give some vague story of their connection with a race who perished with small-pox, but who, or whence, or of what degree of civilization they were, no clue is left. 
It must be said moreover that a perusal of the works written about the mounds, especially of the very large contributions to the subject found in the Smithsonian Institution publications, leaves the mind of the reader in a state of thorough confusion and uncertainty. Indeed, the facts relating to the Mound Builders are as perplexing a problem as the purpose of the Pyramids, or the story of King Arthur.

Is it any wonder that we hover about the dark mystery, and find in our researches room for absorbing study, even though we cannot reach absolute certainty? Could you have seen the excitement which prevailed among the half-dozen settlers, I had employed in digging the mound on Rainy River, in August last, when the perfect pottery cup figured below was found, and the wild enthusiasm with which they prosecuted their further work, you would have said it requires no previous training, but simply a successful discovery or two to make any one a zealous mound explorer.

\section{A MOUND DESCRIBED.}

A mound of the kind found in our region is a very much flattened cone, or round-topped hillock of earth. It is built usually, if not invariably where the soil is soft and easily dug, and it is generally possible to trace in its neighborhood the depression whence the mound material has been taken. The mounds are as a rule found in the midst of a fertile section of country, and it is pretty certain from this that the mound builders were agriculturists, and chose their dwelling places with their occupation in view, where the mounds are found. The mounds are found accordingly on the banks of the Rainy River and Red River, and their affluents in the Northwest, in other words upon our best land stretches, but not so far as observed around the Lake of the Woods, or in barren regions.. Near fishing grounds they greatly abound. What seem io have been strategic points upon the river were selected for their sites. The promontory giving a view and so commanding a considerable stretch of river, the point at the junction of two rivers, or the debouchure of a river into a lake or vice versa is a favorite spot. At the Long Sault on Rainy River there are three or four mounds grouped together along a ridye. Here some persons of strong imagination profess to see remains of an ancient fortification, but to my mind this is mere fancy. Mounds in our region vary from 6 to 50 feet in height, and from 60 to 130 feet in diameter. Some are circular at the base, others are elliptical. 


\section{MOUND REGIONS.}

The mounds have long been known as occurring in Central America, in Mexico, and along the whole extent of the Mississippi valley from the Gulf of Mexico to the great lakes. Our Northwest has, however, been neglected in the accounts of the moundbearing region. Along our Red River I can count some six or eight mounds that have been noted in late years, and from the banks having been peopled and cultivated I have little doubt that others have been obliterated. One formerly stood on the site of the new unfinished Canadian Pacific Hotel in this city. The larger number of those known are in the neighborhood of the rapids, 16 or 18 miles below Winnipeg where the fishing is good. In 1879 the Historical Society opened one of these, and obtained a consider. able quantity of remains. It is reported that there are mounds also on Nettley Creek, a tributary of the lower Red River, also on Lake Manitoba and some of its affluents. During the past summer it was my good fortune to visit the Rainy River, which lies some half way of the distance from Winnipeg to Lake Superior. In that delightful stretch of country, extending for 90 miles along the river there are no less than 21 mounds. These I identify with the mounds of Red River. The communication between Red and Rainy River is effected by ascending the Red Lake River, and coming by portage to a river running from the south into Rainy River. Both Red and Rainy River easily connect with che head waters of the Mississippi. Our region then may be regarded as a self-contained district including the most northerly settlements of the strange race who built the mounds. I shall try to connect them with other branches of the same stock, lying further to the east and south. For convenience I shall speak of the extinct people who inhabited our special region as the fakawgamis, or farthest north mound builders.

\section{MOUND VARIETIES.}

The thirty or forty mounds discovered up to this time in this region of the Takawgamis have, so far as examined, a uniform structure. Where stone could be obtained there is found below the surface of the ground a triple layer of flat limestone blocks, placed in an imbricated manner over the remains interred. In one mound, at the point where the Rainy Lake enters the Rainy River, there is a mound situated on the property of Mr. Pither, Indian agent, in which there was found on excavation, a structure of logs some 10 feet square, and from six to eight feet high. In all the others yet opened the structure has been simply of earth 
of various kinds heaped together. It is possible that the mound containing the log erection may have been for sacrifice, for the logs are found to have been charred. One purpose of all the mounds of the Takawgamis was evidently sepulture; and in them all, charcoal lumps, calcined bones and other evidences of fire are found. It would seem from their position that all the mounds of this region were for the purpose of observation as well as sepulture. The two purposes in 10 way antagonize. For the better understanding of the whole I have selected the largest mound of the Takawgamis yet discovered, and will describe it more minutely.

\section{THE GRAND MOUND.}

It is situated on the Rainy River, about 20 miles from the head of Rainy River. It stands on a point of land where the Missachappa or Bowstring River and the Rainy River join. There is a dense forest covering the river bank where the mound is found. The owner of the land has made a small clearing, which now shows the mound to some extent to one standing on the deck of a steamer passing on the river. The distance back from the water's edge is about 50 yards. The mound strikes you with great surprise as your eye first catches it. Its crest is covered with lofty trees, which overtop the surrounding forest. These thriving trees, elm, soft maple, basswood and poplar, 60 or 70 feet high now thrust their root tendrils deep intu the aforetime softened mould. A foot or more of a mass of decayed leaves and other vegetable matter encases the mound. The brushy surface of the mound has been cleared by the owner, and the thicket formerly upon it removed. The circumference of one fine poplar was found to be 4 feet 10 inches; of another tree, 5 feet 6 inches, but the largest had lately fallen. Around the stump the last measured seven feet. The mound is eliptical at the base. The longest diameter, that is from east to west, the same direction as the course of the river, is 117 feet. The, corresponding shorter diameter from north to south is 90 feet. The circumference of the mound is consequently 325 feet. The highest point of the mound is 45 feet above the surrounding level of the earth. As to height the mound does not compare unfavorably with the celebrated mound at Miamisburg, Ohio, known as one of the class of "observation mounds," which is 68 feet high and 852 feet around the base. In addition to its purpose of sepultire, everything goes to show that the "Grand Mound" of Rainy River was for observation as well. 
THE EXCAVATION.

Two former attempts had been made to open this mound. One of these had been made in the top, and the large skull before you was then obtained. A more extensive effort was that made in 1883 , by Mr. E. McColl, Indian agent, Mr. Crowe, H. B. Co. officer of Fort Frances, and a party of men. Their plan was to run a tunnel from north to south through the base of the mound. They had penetrated some ten or fifteen feet, found some articles of interest, and had then given up the undertaking. Having employed a number of men, settler's in the neighborhood, I determined to continue the tunnel for a certain distance through the mound, all the way if indications were favorable, and then to pierce the mound from the top. 'The men in two parties went industriously to work on the opposite sides, working toward each other, making a tunnel about eight feet in diameter. The earth though originally soft soil had becume so hard that it was necessary to use a pick axe to loosen it for the spade. A number of skeletons were found on the south side, but all I should say within ten feet from the original surface of the mound. As we penetrated the interior fewer remains were continually found. The earth gave many indications of having been burnt. At one point the pick-axe sank ten inches into the hard wall. This was about fifteen feet from the outside. The excavator then dug out with his hand from a horizontal pocket in the earth eight or ten inches wide and eighteen or twenty inches deep, a quantity of soft brown dust, and a piece of bone some four inches long, a part of a human forearm bone. This pocket was plainly the original resting place of a skeleton, probably in a sitting posture. As deeper penetration was made brown eartlyy spots without a trace of bone remaining were some upon. The excavation on the south side was continued for thirty feet into the mound, but at this stage it was evident that bones, pottery, etc., had been so long interred that they were reduced to dust. No hope seemed to remain now of finding objects of interest in this direction, and so with about forty feet yet wanting to complete the tunnel, the search was transferred to the top of the mound.

\section{THE UPPER CUT.}

Beginning on the crest of the mound, the mould was removed over a considerable space, and though some trouble was found from the presence of the roots of the growing trees, yet three or four feet from the surface human bones and skeletons began to occur. In some cases a complete skeleton was found, 
in other cases what seemed to be a circle of skulls, buried alongside charred bones, fragments of pottery and other articles. Several different excavations were made on the mound surface, and it was found that every part from the base to the crest contained bones and skeletons, to the depth of from six to ten feet as already said ; bones and articles of interest were found thus far ; deeper than this nothing. I shall now describe the articles found in this mound, and refer in some cases to what has been found in the other mounds of the Takawgamis.

\section{NATURAL PRODUCTS.}

1. Bones. Of the bones found, the skulls were the most interesting. In some cases it would seem as if they alone of the bones had been carried trom a distance, perhaps from a distant part of the mound builders' territory, from a battle field or some other spot. In some cases this was proved, by the presence in the eye-sockets and cavities of clay of a different kind from that of the mound, showing a previous interment. The mound was plainly a sacred spot of the family or sept. Before you are pieces of charred bone. Of the bones unburnt some were of large size. There are before us two skulls, one from the grand mound, the other from the Red Rivel mound opened by the Society in 1879 . The following are the measurements of the two skulls which I have made carefully; and alongside the average measurements of the Brachycephalic type given by Dr. Daniel Wilson, as well as of the Dolichocephalic :

\begin{tabular}{|c|c|c|c|c|}
\hline & Average & RaINy RIver & Red RIVER & AvERAGE \\
\hline & $\begin{array}{l}\text { DOLICHO- } \\
\text { CEPHALIC. }\end{array}$ & SKULL. & SKULL. & $\begin{array}{l}\text { BRACHY- } \\
\text { CEPHALIC. }\end{array}$ \\
\hline Longitudinal diameter..... & .. 7.24 & $7.3 \mathrm{in.}$ & 6.7 & 6.62 \\
\hline Parietal diameter ........... & 5.47 & 5.8 & 5.5 & 5.45 \\
\hline Vertical 6 "........... & 5.42 & 6.2 & 5.8 & 5.30 \\
\hline " $\quad \ldots \ldots \ldots \ldots$ & $\ldots \quad 4.36$ & 4.2 & 3.7 & 4.24 \\
\hline Intermastoid Arch ........ & $\ldots 14.67$ & 15.3 & 15.6 & 14.63 \\
\hline Intermastoid line .......... & .. 4.23 & 5.8 & 4.3 & 4.25 \\
\hline Occipito frontal Arch..... & ... 14.62 & 17. & 13.8 & 13.85 \\
\hline Horizuntal circumference & e. 20.29 & 22.3 & 19.6 & 19.44 \\
\hline
\end{tabular}

From this it will be seen that the Red River mound skulls agree with the Toltecan Brachycephalic type; and the Rainy River skull while not so distinctly Brachycephalic yet is considerably above the average of the Dolichocephalic type.

2. Woorl. As already stated it is only in some of the mounds that charred wood is found. This specimen is from the mound 
at Contcheteheng, at the head of Rainy River. It stands beside the Rapids. This mound has supplied many interesting remains. From this fact as well as from its situation, I would hazard the opinion that here, as at the great Rainy River Falls, three miles farther down, there were villages in the old mound building days. It is a fact worthy of notice that the site of the first French Fort on Rainy River, St. Pierre built by Verandrye in 1731, was a few hundred yards from this mound.

3. Bark. Specimens of birch bark were found near by the bones. It was no doubt originally used for swathing or wrapping the corpses buried. That a soft decayable substance such as bark, should have lasted while a number of bones had decayed nay seem strange. No doubt this may be explained in the same way as the presence among the remains in Hochelaga, on the Island of Montreal, of preserved fragments of maize, viz.: by its having been scorched. The pieces of bark seem to have been hardened by scorshing.

4. Earth. The main earth of the mound is plainly the same as that of the soil surrounding it. By what means the earth was piled up, is a question for speculation. It seems a matter of small moment. Possibly that the earth was carried in baskets, or vessels of considerable size is sufficient to account for it. My theory is that the mound was not erected by a vast company of busy workers as were the pyramids, but that it was begun at first for purposes of observation, that as interments were from time to time made in it sufficient earth was carried up to effect the purpose, until in centuries the enormous aggregate of earth was formed. Among the earth of the mound are also found in spots, quantities of red and yellow ochre. The fact that the skulls and bones seem nften to have a reddish tinge, goes to show that the ochre was used for the purpose of ornamentation. Sometimes a skull is drawn out of the firm cast made by it in the earth, and the cast is seen to be reddened by the ochre which was probably smeared over the face of the slain warrior. The ochre is entirely foreign to the earth of which the mound is made, but being earthy remains long atter even pottery has gone to decay.

5. Ore. Lying near this skull as if they had been placed in the hands of the corpse were tw.) pieces of metallic ore, one of which is before you. A fresh section of it shows it to be Arsenical Iron Pyrites, each piece weighing four or five ounces. No doubt the shining ore and its heavy weight attracted notice, 
although it is of no commercial value. The probabilities are that this ore was regarded as sacred, and possibly having been considered valuable was placed beside the corpse as the ancient obolus was laid beside the departed (treek to pay his fare to crusty Charon.

\section{FiguRe 1.}

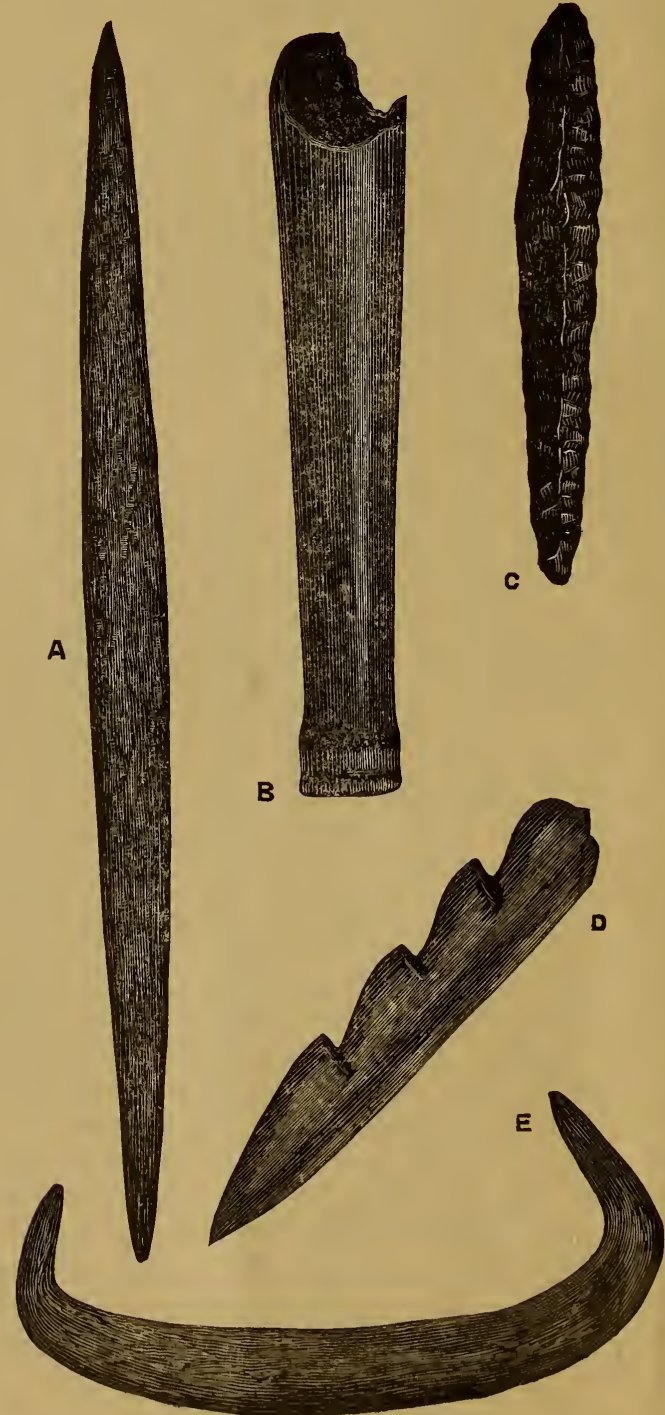

Mound Builders' Implements. 


\section{MANUFACTURED ARTICLES.}

1. Stone Implements. The stone articles found, no doubt form a very small proportion of the implements used by the lost race. I am able to show you three classes of implements.

(a.) Scrapers. (See c. Figure 1.) These were made after the same manner and from the same material as the flint arrow heads, found so commonly all over this continent. They are usually of an oval or elongated diamond shape, of various thicknesses, but thin at the edges. Their purpose seems to have been to assist in skinning the game, the larger for larger game, the smaller for rabbits and the smaller fur bearing animals. Probably these implements were also used for scraping the hides or skins manufactured into useful articles.

(b.) Stone Axes and Malls. In the mound on Red River was found the beautiful axe of crystalline limestone, which approaches marble. From the absence of stone so far as we know of this kind in this neighborhood, it is safe to vonclude that it come from a distant locality. There are also gray stone celts and hammers used for crushing corn, for hammering wood and bark for the canoes, and other such like purposes, in time of peace; and serving as formidable weapons in time of war. In the mound on the Red River a skull was discovered having a deep depression in the broken wall, as if crushed in by one of these impliments.

(c.) Stone Tubes. (See B. Fig. 1.) These are among the most difficult of all the mound-builders' remains to give an opinion upon. They are chiefly made of a soft stone something like the pipestone used by the present Indians which approaches soapstone. The hollow tubes (see figure B.) vary from three to six inches in length, and are about one-half an inch in diameter. They seem to have been bored out by some sharp instrument. Schoolcraft, certainly a competent Indian authority states that these tubes were employed for astronomical purposes, that is to look at the stars. This is unlikely; for though the race, with which I shall try to identify our mound builders are said, in regions further south, to have left remains showing astronomical knowledge, yet a more reasunable purpose is suggested for the tubes. From the teeth marks around the rim, the tubes were plainly used in the mouth, and it is becoming generally agreed that they were conjuror's cupping instruments for sucking out as the medicine men pretended to be able to do the disease from the body. The custom survives in some of the present In- 
dian tribes. A lady friend of mine informs me that she has a bone whistle taken from a mound in the Red River district.

2. Horn Implements. (See D. Figure 1.) The only implement of this class that we have yet found is the fish spear head (Fig. D.). It was probably made from the antlers of a deer killed in the chase. Its barbed edge indicates that it was used for spearing fish. It is in a fair state of preservation.

3. Copper. No discovery of the mounds so fills the mind of the Archaeologist with joy as that of copper implements. Copper mining has now by the discovery in the Lake Superior region, of mining shafts long deserted, in which copper was quarried by stone hammers on a large scale, been shown to have been pursued in very ancient times on this continent. It is of intense interest for us to know that not only are there mines found on the south side of Lake Superior, but also at Isle Royale, on the north side just at the opening of Thunder Bay, and immediately contiguous to the Grand Portage, where the canoe route to Rainy River, so late as our own century, started from Lake Superior. According to the American Geologists the traces for a mile are found of an old copper mine on this Island. One of the pits opened showed that the excavation had been made in the solid rock to the depth of nine feet, the walls being perfectly smooth. A vein of native copper eighteen inches thick was discovered at the bottom. Here is found also, unless I am much mistaken, the mining location whence the Takawgamis of Rainy River obtained their copper implements. Two copper implements are in our possession, one found by Mr. E. Mcloll in the grand mound, and the other by Mr. Alexander Baker in a small mound adjoining this.

(a.) Copper Needle or Drill. (See A. Fig. 1.) This was plainly used for some piercing or boring purpose. It is hard, yields with difficulty to the knife, and is considered by some to have been tempered. It may have been for drilling out soft stone implements, or was probably used for piercing as a needle soft fabrics of bark and the like, which were being sewed together.

(b.) Copper Cutting Knife. (See E. Fig. 1.) This has evidently been fastened into a wooden handle. It may have been used for cutting leather, being in the shape of a sadd'er's knife, or was perhaps more suited for scraping the hides and skins of animals being prepared for use. 
Some twenty miles above the mound on the Rainy River at Fort Frances a copper chisel buried in the earth was found by Mr. Pither, then H. B. Company agent, and was given by him to the late Governor McTavish. The chisel was ten inches long, was well tempered, and was a good cutting instrument. Another copper implement is in the possession of our Society, which was found buried in the earth 100 miles west of Red River.

All these, I take it, were made from copper obtained from Isle Royale on Lake Superior.

4. Shell Ornaments. Traces are found in the mound, of the fact that the decorative taste, no doubt developed in all ages, and in all climes, was possessed by the Takawganis.

(a.) Sea Shells. Important as pointing to the home and trading centres of the mound builders is the presence among the debris of the mound, of sea shells. We have three specimens found in the grand mound. Two of them seem to belong to the genus Natica, the other to Marginella. They have all been cut or ground down on the side of the opening of the shell, so that two holes permit the passage of a string, by which the beads thus made are strung together. The fact that the genera to which the shells belong are found in the sea, as well as their highly polished surface show these to be marine; and not only so but from the tropical seas, either we suppose from the Gulf of Mexico or from the Californian coast.

(b.) Fresh Water Shells. In all the mounds yet opened, examples of the Unio, or River Mussel, commonly known as the clam have beed found. They are usually polished, eut into symmetrical shapes, and have holes bored in them. We have one which was no doubt used as a breast ornament, and was hung by a string around the neck. In the bottom of a nearly complete pottery cup, found in the grand mound, which went to pieces as we took it out, there was lying a polished clam shell. The clam still abounds on Rainy River. Six miles above the mound, we saw gathered together by an industrious housewife hundreds of the sarne species of clam, whose shells she was in the habit of pulverizing for the benefit, of her poultry.

5. Pottery. (a.) Broken. It seems to be a feature of every mound that has been opened that fragments of pottery have been unearthed. The Society has in its possession remains of twenty or thirty pottery vessels. They are shown to be portions of dif- 
ferent pots, hy their variety of marking. The pottery is of a coarse sort, seemingly made by hand and not upon a wheel, and then baked. The markings were made upon the soft clay, evidently with a sharp instrument, or sometimes with the finger nail. Some pieces are found hard and well preserved; others are rapidly disintegrating. As stated already, in the grand mound, a vessel some five inches in diameter was dug up by one of the workers, filled with earth, which though we tried earnestly to save it, yet went to pieces in our hands The frequency with which fragments of pottery are found in the mounds has given rise to the theory that being used at the time of the funeral rites the vessel was dashed to pieces as was done by some ancient nations in the burial of the dead. This theory is made very doubtful indeed by the discovery of the

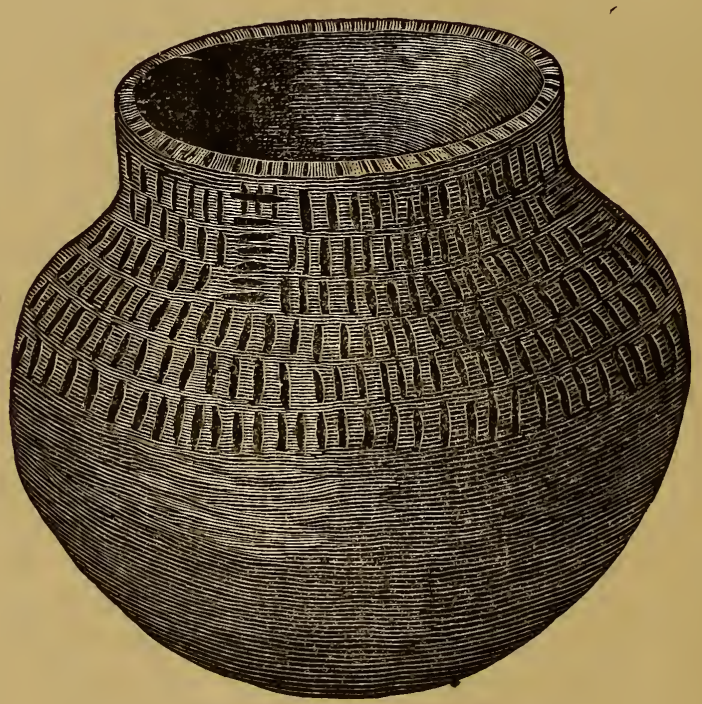

FIGURE 2.

(b.) Complete Puttery cup. So far as I know this is the only complete cup now in existence in the region northwest of Lake Superior, though several others are said to have been discovered and been sent to distant friends of the finders. This cup, belonging now to the Historical Society was found in the grand mound, in company with charred bones, skulls, and other human bones, lumps of red ochre, and the shells just described. The dimensions of the cup are as follows: 
Mean diameter at top of rim ......... 2.09 inches.

Greatest mean diameter.............. 3.03

Height...................... 249 "

Thickness of material. ................. . .092 "

Weight.................... - - oz.

Whether the cup was intended for use as a burial urn, or simply for ordinary use it is difficult to say.

Now, in endeavoring to sum up the results a few points need some discussion.

1. Who were the people who erected the mounds? Judging from the following considerations, I should say they were

\section{NOT AN INDIAN RACE.}

Whoever built the mounds had a faculty not possessed by modern Indians. Building instincts seem hereditary. The beaver and the musk rat build a house. Other creatures to whom a dwelling might be serriceable, such as the squirrel obtain shelter in another way. And races have their distinctive tendencies likewise. It never occurs to an Indian to build a mound. From what has been already said as to the fertile localities in which the mounds are found we are justified in believing that their builders were agriculturists. Dr. Dawson in Montreal by the use of the microscope detected grains of charred corn in the remains of Hochelaga. I have examined a small quantity of the dust taken from one of the shells found in the grand mound, with the microscope, and though I am not perfectly certain, yet I believe there are traces of some farinaceous substance to be seen. On skirting the shores of the Lake of the Woods into which Rainy River runs, at the present time, you are struck by the fact that there are no Canadian farmers there, and likewise that there are no mounds to be seen, while along the banks of Rainy River both the agriculturist is found cultivating the soil and the mounds abound. It would seem to justify us in concluding that the farmer and the mound builder avoided the one locality because of its barren rocky character and took to the other because of its fertility. Moreover the continual occurrence of pottery in the mounds shows that the mound-builders were potters as well, while none of the tribes inhabiting the district have any knowledge of the art of pottery. The making of pottery is the occupation peculiarly of a sedentary race, and hence 
of a race likely to be agriculturists. As it requires the building faculty to originate the mounds, so it requires the constructive faculty to make pottery. In constructive ability our Indians are singularly deficient, just as it is with greatest difficulty that they can be induced even on a small scale to practice agriculture. It has been objected to this conclusion that the Indians can make a canoe, which is a marvel in its way. But there is a great difference in the two cases. In the canoe all the materials remain the same. The approximation to a chemical process makes the pottery manufacture a much more complicated matter. Indeed the Indian in token of his surprise at his success in being even able to construct a canoe, states in his tradition that it is the gift of the Manitou. Furthermore the mound builder used metal tools, and was probably a metal worker. It is true the copper implements mentioned, as having been lound were brought to Rainy and Red Rivers. I have, however, pointed out the intimate connection judging by the line of transport subsisting between Rainy River and Lake Superior, the mining locality for copper. To sink a mine in the unyielding Huronian rock of Lake Superior, with mallet and hammer and wedge and fire, take out the native copper, work it into the lesired tools, and then temper these requires skill and adaptation unpossessed by the Indians. For centuries we know that the Lake Superior mines, in which are found tools and timber constructions, have been buried, filled in for ten feet with debris, and have rank vegetation and trees growing upon them. It is certain that the Indian races, even when shown the example, cannot when left alone follow the mining pursuit. Not only then by the ethnological, and other cata cited do we conclude that the mound builders belong to a different race from the present Indians, but the tradition of the Indians is to the same effect. Then

\section{WHO WERE THE MOUND BUILDERS?}

I would lead you back now to what little we know from the different sources, of the early history of our continent. When the Spaniards came to Mexico in the early years of the 16th century, Montezuma, an Aztec prince was on the throne. The Aztecs gave themselves out as intruders in Mexico. They were a bloody and warlike race, and though they gave the Spaniards an easy victory it was rather a reception, for they were overawed by superstition as to the invaders. They stated that a few centuries before, they had been a wild tribe on the high country of the Rio Grande and Colorado, in New Mexico. The access from 
the Pacific up the Colorado would agree well with the hypothesis that the chief sources of the aboriginal inhabitants of America were Mongolian, and that from parties of Mongols landing from the Pacific Isles on the American coast, the population was derived. At any rate the Aztecs stated that before they invaded Mexic ) from their original home, they were preceded by a civilized race, well acquainted with the arts and science, knowing more art and astronomy in particular than they. They stated that they had exterminated this race known as

THE TOLTECS.

The main features of the story seem correct. The Toltecs seem to have been allied to the Peruvians. Their skulls seem of the Brachycephalic type. The Toltecs were agriculturists, were mechanical, industrial, and constructive. In Mexico, and further south in Nicaragua, as well as northward, large mounds remain which are traced to them. According to the Aztec story the Toltecans spread in Mexico from the seventh to the twelfth century at which latter day they were swept away. My theory is that it was this race-which must have been very numerouswhich either came from Peru in South America, capturing Mexico and then flowing northward; or perhaps came from New Mexico, the American Scythia of that day, and sending one branch down into Mexico, sent another lown the Rio Grande, which then spread up the Mississippi and its tributaries The mounds mark the course of this race migration. They are found on the Mississippi. One part of the race seems to have ascended the Ohio to the great lakes and the St. Lawrence, another went up the Missouri, while another ascended the Mississippi proper and gained communication from its head waters with the Rainy and Red Rivers. When then did the crest of this wave of migration reach its furthest northward point? Taking the seventh century as the date of the first movement of the Toltecs toward conquest in Mexico, I have set three or four centuries as the probable time taken for multiplication and the displacement of former tribes, until they: reached and possessed this northern region of "The Takagamies," or far north mound builders. This would place their occupation of Rainy River in the eleventh century. Other considerations to which I shall refer seem to sustain this as the proballe date. The grand mound is by far the

\section{LARGEST MOUND}

on Rainy River. It is likewise at the mouth of the Bowstring 
River, which is its largest tributary and affords the readiest means of access from the Mississippi up which the Toltecan flood of emigration was surging. My theory is that here in their new homes, for three centuries they multiplied, cultivated the soil, and built the mounds which are still a monument to their industry. Here they became less warlike because more industrious, and hence less able to defend themselves. I have already stated that the

\section{AZTEC WHIRLWIND OF CONQUEST}

swept into Mexico from the Northwest about the twelfth cencentury. The sanguinary horde partly destroyed and partly seized for its own use the civilization of the Toltecans. We have specially to do with an Aztec wave that seems to have surged up the valley of the Mississippi. As the great conquering people captured one region, they would settle upon it, and send off a new hive of marauders. Indian tribes, numerous but of the same savage type, are marked by the old Geographers as occupying the Mississippi valley. It was when one part of the northern horde came up the valley of the Ohio, as the Savage Iroquois, and another up the head waters of the Mississippi as the Sioux, the tigers of the plains, that we berame familiar in the sixteenth century with this race. The French recognized the Sioux as the same race as the Iroquuis and called them "Iroquets" or little Iroquois. The two nations were confederate in their form of government; they had all the fury of the Aztecs, and resemblances of a sufficiently marked kind are found between Sioux or Dakota and the Iroquois dialect, while their skulls follow the Dolichocephalic type of cranium. With fire and sword the invaders swept away the Toltecs; their mines were deserted and filled up with debris; their arts of agriculture, metal working: and pottery making were lost; and up to the extreme limits of our country of the Takawgamis, only the mounds and their contents were left.

\section{OUR HISTORIC ERA}

saw the sxpiring blaze of this tremendous contlagration just as the French arriverl in Canada. Cartier sas a race in 1.535 in Hochelaga, who are believed to have had Brachyı:ephalic crania, who were agriculturists, used at least implements of metal, dwelt in large houses, made pottery and were constructive in tendency. In 1608 when Champlain visited the same spot, there were none of the Hochelagans remaining. This remnant of the Toltecans 
had been swept out of existence between the Algonquin wave from the east and the Iroquois from the southwest. The French heard of a similar race called the Eries and of another the Neutrals, who had the same habits and customs as the vanished Hochelagans, but who had been visited by the scourge of the Iroquois on the Ohio as they ascended it, and had perished. Thus from the twelfth century, the time set for the irruption of the savage tribes from New Mexico, two or three centuries would probably suffice to sweep away the last even of the farthest north Takawgamis. This, say the fifteenth century, would agree very well, not only with time estimated by the early French explorers, but also with the tradition of the Crees who claim that for three or four centuries they have lived sole possessors upon the borders of Lake Superior, Lake of the Woods, and Iake Winnipeg. Our theory then is that the mound builders occupied the region of Rainy and Red Rivers from the eleventh to the fifteenth centuries. Their works remain.

\section{HOW OLD}

then are the mounds? If our conclusions are correct the oldest mound in our region cannot exceed 800 years, and the most recent must have been completed upwards of 400 years ago. Look at further considerations, which lead to these conclusions. We learn, that 200 years ago, viz.: in 1683, the "Clistinos" and "Assinipouals" (Crees and Assiniboines) were in their present country. The Crees were at tlat time in the habit of visiting both Lake Superior and Hudson's Bay for the purpose of trade. 'They were then extensive nations and no trace of a nation which preceded them was got from them. The fallen tree on the top of the grand mound, judging by the concentric rings of its trunk is 150 or 200 years old, and yet its stump stands in a foot or niore of mould that must have taken longer than that time to form. Even among savage nations it would take upwards of half a dozen generations of men, to lose the memory of so great a catastrophe as the destruction of a former populous race. Then some 400 years ago would agree with the time of extermination of the Hochelagans, or with the destruction of the Fries, who according to Labontan were blotted out before the French came to the continent. The Hochelagans, Eries, and Takawgamis being northern in their habitat, I take it were among the last of the Toltecans whosurvived. The white man but arrived upon the scene to succeed the farmer, the metal worker and the potter, who had passed away so disastrously, and to be the avenger of the lost race, in driving before him the savage red man 
THE EARLIEST MOUND.

I believe our grand mound to be the earliest in the region of the Takawgamis. It is the largest in the region. It will be seen by reference to figure 3 that I arrive at its age in the follow-

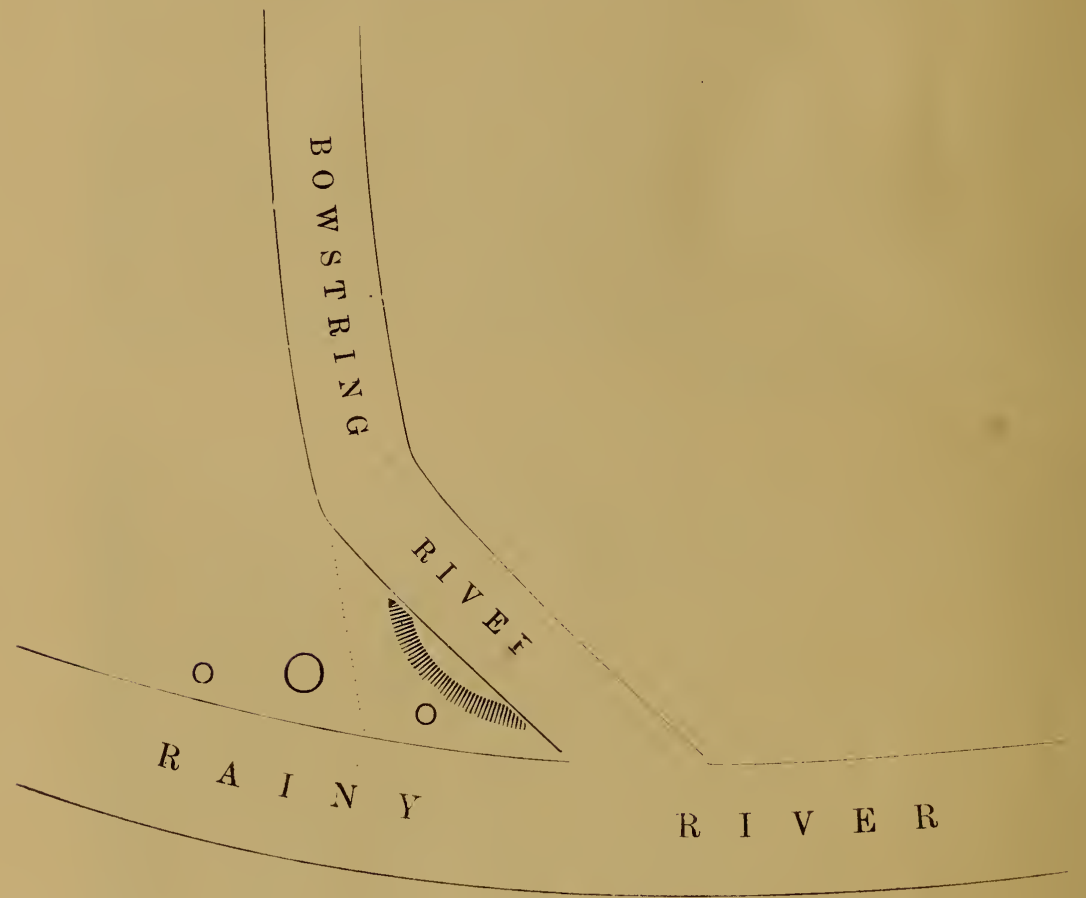

Figure 3.

ing way. Where it now stands, so striking an object, it is about one-third of a mile above the point where the Bowstring River enters the Rainy River. If however from the top of the mound you look southward through the trees a view may be got of the silver stream of the Bowstring, coning as if directly toward the mound. Originally no doubt this tributary flowed close by the mound, for the mound wonld undoubtedly be built on the extreme point. But as from year to year the Bowstring River deposited the detritus carried down by it, it formed a bank or bar, and was gradually diverted from its course, until now, the peninsula some hundreds of yards across its base, has become up- 
wards of a third of a mile long. I infer that this peninsula, which I should say contains some seventy acres has been formed since the mound-which from its position seems for observation as well as for sepulture-was begun. Some 200 yards down the point from the grand mound occurs another small mound. This is some eight or ten feet high, and fifty or sixty feet across. Along the point and close past this small mound runs an old water course. now a treeless hay meadow. At high water in spring, as I ascertained, the river still sends its surplus water by this old channel. My position is that the 200 yards of earth between the site of the grand mound and that of the small mound was deposited after the grand mound was begun, and before the commencement of the small mound. Undoubtedly this small mound as well as a similar one not far up the river from the grand mound, were begun on account of the laborious work of carrying bones and earth to such a height, and on account of the numerous interments which have left the surface of the grand mound a bone pile. This is shown by the small mound being on a site more recent than that of the large mound. Suppose a hundred years to have sufficed to raise the small mound to its height when the devastating ruin of the Sioux slaughtered the last mound builder and checked the mound. From our previous position this wo d]d represent a point some 500 years ago. But during this 500 years according to our hypothesis all of the point of land below the small mound, that is to say, about 300 yards in length, has been formed. The question then is, how long at the same rate must it have taken the 200 yards between the two mounds to form. This brings us then to a point say 300 years before the time of beginning of the small mound. We thus arrive at about 800 years ago as the time when the grand mound was begun. It will thus be seen that we have reached back to the eleventh cen. tury, the time previously deduced from historic date for the arrival of the Toltecans on the Rainy River.

\section{CONCLUSION.}

Our investigation has now come to an end. I have led you to examine the few fragments of a civilization which it would be absurd to declare to have been of the very highest type, but yet of a character much above that of the wandering tribes, which, with their well-known thirst for blood, destroyed the very arts and useful habits which might have bettered their condition. The whirlwind of barbarian fury is ever one which fills peaceful nations with terror. We may remember how near in the 
"Agony of Canada," the French power was to being swept out of existence by the tierce fury of the Iroquois-up to that time always victorious. We may remember how civilization in Minnesota was thrown back by the Sioux nnassacre of 1861 . It is only now by persistent and unwearied efforts that we can hope to conquer the Indians by the arts of peace, and by inducing him to take the hoe in place of the tomahawk, to meet nature's obstacles Who can fail to heave a sigh for our northern mound builders, and to lament the destruction of so vast and civilized a race as the peaceful Toltecans of Mexico, of the Mississippi, and of the Ohio, to which our Takawgamis belonged? After all, their life must in the main, ever remain a mystery.

\section{THE LOST RACE.}

"One of our visits to the mound was at night."

Oh, silent mound! thy secret tell!

God's acre gazing toward the sky,

'Midst sombre shade 'neath angel's eye

Thou sleepest till the domesday knell.

Sweet leaflets, on the towering elms,

Oh whisper from your crested height!

Or have lost forests borne from sight

The secret to their buried realms?

Stay, babbling river, hurrying past,

Cans't thou, who saw'st the toilers build,

Not picture on thy bosom stilled,

Jife-speaking shadows long since cast?

Or, echo, mocking us with sound,

Repeat the busy voice, we prav,

Of moiling thousands, now dull clay,

And waken up the gloom profound.

Pale, shimmering ghosts that flit around,

While spade and mattock death-fields glean,

Open with words from the unseen

The mysteries now in cerements bound.

No answer yet! We gaze in vain.

With lamp and lore let science come.

Now, clear eyed maiden!!-You, too. dumb !

Your light gone out!!--'tis night again.

And is this all ? an earthen pot!

A broken spear! a copper pin!

Earth's grandest prizes counted in,

A burial mound ! - the common lot!

Yes! this were all; but o'er the mound,

The stars, that fill the midnight sky,

Are eyes from Heaven that watch on high

Till domesday's thrilling life-note sound. 


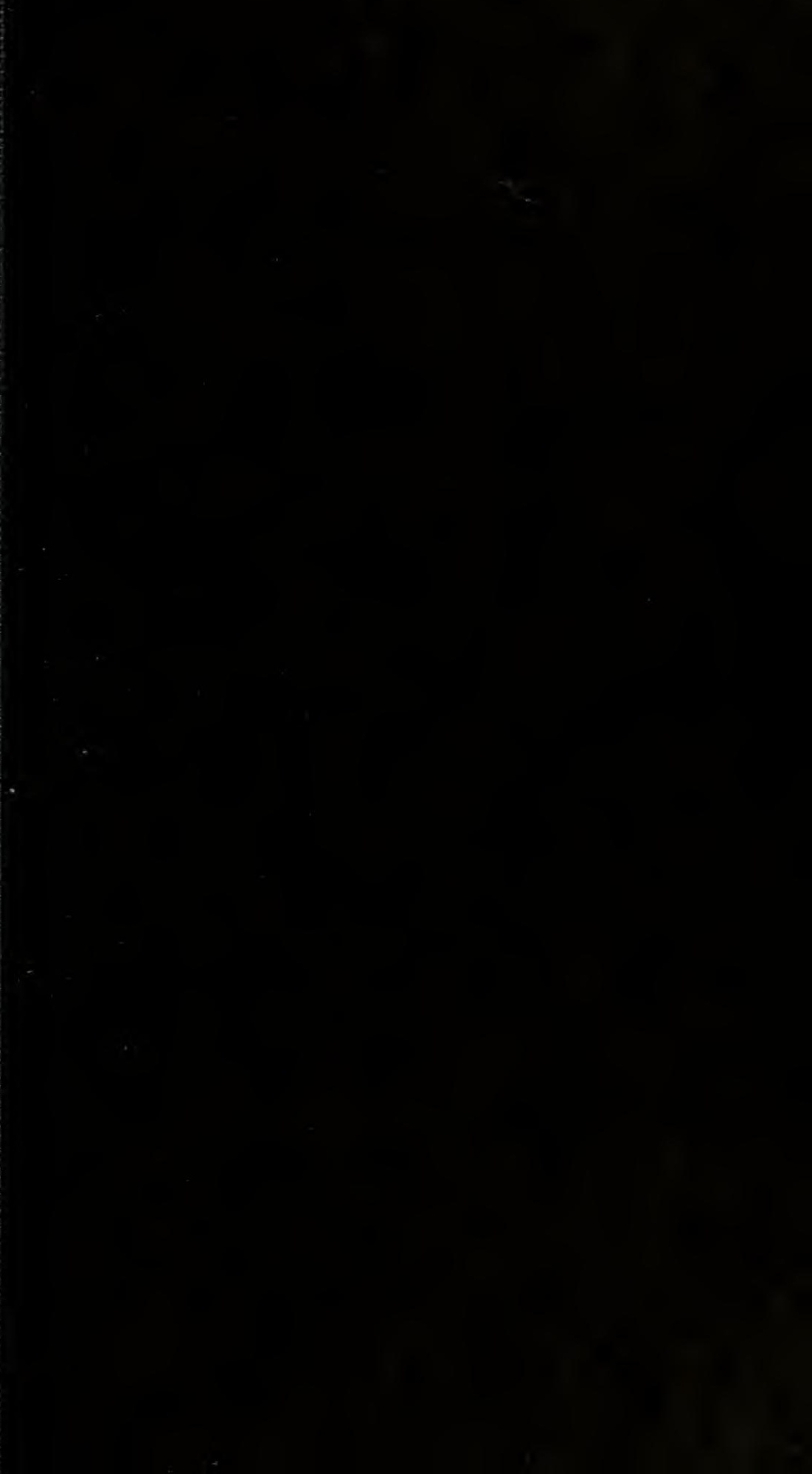




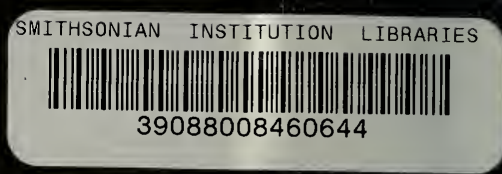

